SRĐAN VUJIČIĆ, Ph.D. student ${ }^{1}$

(Corresponding author)

E-mail: srdjan.vujicic@unidu.hr

ĐANI MOHOVIĆ, Ph.D. ${ }^{2}$

E-mail:dmohovic@pfri.hr

ROBERT MOHOVIĆ, Ph.D. ${ }^{2}$

E-mail: mohovic@pfri.hr

1 University of Dubrovnik, Maritime Department

Ćira Carića 4, 20000 Dubrovnik, Croatia

2 University of Rijeka, Faculty of Maritime Studies

Studentska ulica 2, 51000 Rijeka, Croatia
Safety and Security in Traffic Preliminary Communication

Submitted: 16 June 2016

Accepted: 16 Nov. 2016

\title{
A MODEL OF DETERMINING THE CLOSEST POINT OF APPROACH BETWEEN SHIPS ON THE OPEN SEA
}

\begin{abstract}
The main objective of this paper proposes the model for the decision-making process with the intent of optimising the collision avoidance in the crossing situation on the open sea. Using the IMO Resolution standards for ship manoeuvrability, along with the equation for determining the required distance of the closest point of approach (CPA) and other parameters for own ship and the target ship, it can be possible to determine the distance at which to start alternation and collision avoidance. The research results that involved ship officers and captains with the aim of determining the Closest Point of Approach (CPA) showed a very subjective assessment method. The presented model obtained by the simulation method to determine the CPA between ships on the open sea is the key finding of this research and leaves room for further research and its further implementation on unmanned ships.
\end{abstract}

\section{KEY WORDS}

collision avoidance decision; ship domain; rudder steering simulation;

\section{INTRODUCTION}

Statistics shows that $80 \%$ of collisions at sea are caused by gross negligence, breach of the regulations or wrong decisions made by the navigator. According to Gale et al. [1] $24 \%$ of collisions are caused by the insufficient situation assessment, $23 \%$ by poor control of situation, and $13 \%$ by officers who were unaware of hazards. Other causes comprise poor communication both between the ships and on the bridge, the failure to comply with the Convention on the International Regulations for Preventing Collisions at Sea, 1972 (COLREGs) and the influence of fatigue on making timely decisions. According to Marine Accident Investigation Branch 2004 (MAIB 2004) [2], for the past 10 years, collisions of ships have made up to $55 \%$ of accidents. The collision risk assessment and the decision-making process to prevent collisions at sea are based on the criteria of maritime rules and on the experience and knowledge of the officers. The closest point of approach (CPA), time to the closest point of approach (TCPA), and distance to the closest point of approach (DCPA) are not regulated by maritime rules, but are left to the discretion of the ship officer or to the decision of a maritime company made on the grounds of the safety management system (SMS). The Faculty of Maritime Studies in Rijeka and the University of Dubrovnik have conducted a research under the projects connected to the EU project "Avoiding Collision at Sea" so as to determine the CPA in the unlimited area of navigation, usually called open sea. For the purpose of this paper the research has been carried out at the University of Dubrovnik on the Kongsberg's (Norwegian manufacturer) Polaris ship bridge simulator, approved by the DNV on different types of ships. The trajectory of ships at various rudder deflection angles and increased turning circle were observed under the influence of currents, waves and wind. The obtained results helped to make the model for determining the CPA within the unlimited area of navigation.

\section{PREVIOUS RESEARCH ON THE DISTANCE TO THE CLOSEST POINT OF APPROACH}

The main objective of plying is the transport of goods or passengers between the port of origin and the port of destination, while maintaining safe navigation by avoiding the navigational hazards. The collision with other ships is one of the greatest hazards that is to be avoided. Determining the risk of collision on time and properly assessing the CPA and TCPA are the basis for collision risk assessment. Determining safe CPA depends on a number of factors among which the most important are ship manoeuvrability, meteorological and oceanological conditions, and the area of navigation. Many authors have dealt with the CPA, which is in literature mostly referred to as a domain, 

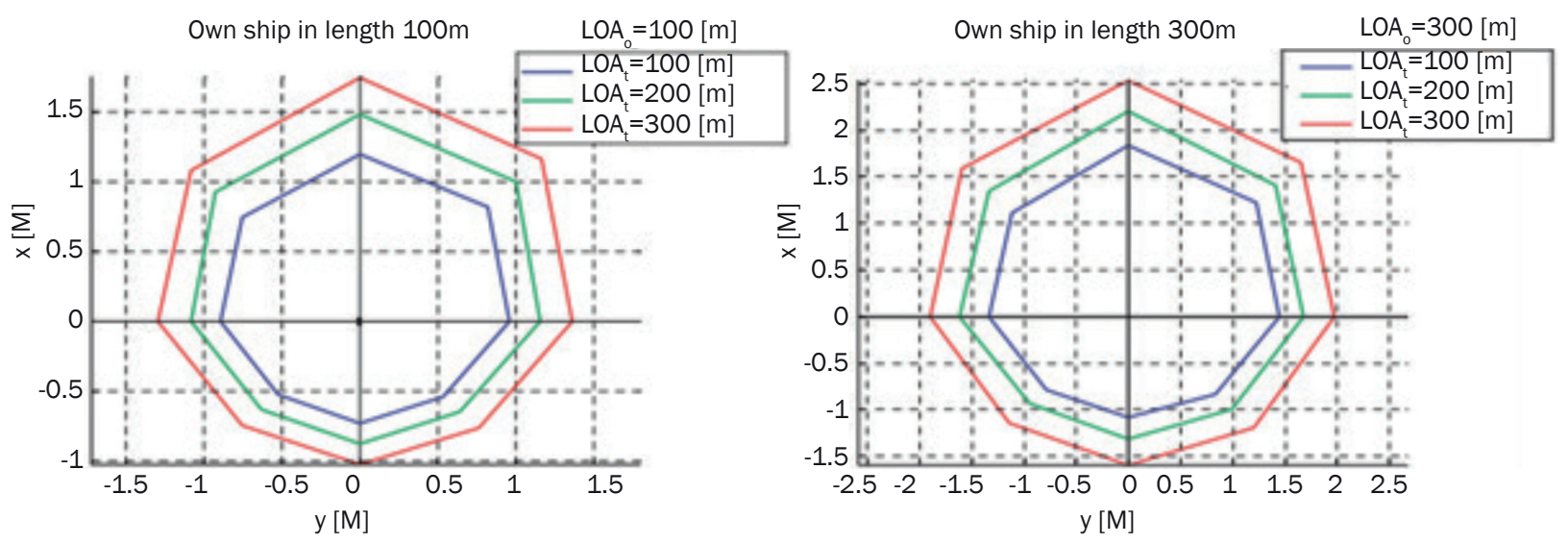

Figure 1 - Ship domain DS, ships length 100, 200 and 300 m passing each other

and in their research they have defined various geometric shapes for the domain, such as circle, ellipse, rectangle, polygon, and other complex shapes.

The domain is defined as the surrounding waters that the navigator wants to keep clear of other ships. This definition allows for a very subjective way of determining the domain. The size of the domain can be determined by statistical methods, i.e. by recording the ship's trajectory, analytic mathematical expressions and artificial intelligence methods. The size of the domain obtained by research in the Japanese waters is presented by Fujii et al. [3]. The domain had the shape of an ellipse whose longer axis amounted to 8 ship lengths and the shorter one to 3.2 ship lengths. According to the statistical approach Goodwin [4] divided the domain into three sectors in conformity with the side lights and the stern light. The distance of the domain border in the sector of green side light was $0.85 \mathrm{M}$, of red side light $0.70 \mathrm{M}$, and in the sector of stern light $0.45 \mathrm{M}$. Davis et al. [5] presented the modified form of Goodwin's domain with the model of eccentric circles from the ship out of the centre of domain. The same year, J.D. Holmes [6] showed the significance of the relative and absolute velocity. He conducted a research with the masters of the vessels and found that the distance where they started the action of avoiding collision on the open sea was $\geq 5 \mathrm{M}$, while in Gibraltar it was $2.5 \mathrm{M}$. Furthermore, according to Codwell [7] the size of the domain boundary, when the ship is on its opposite course, from amidships to starboard is $3.25 \mathrm{M}$, to port side it is $1.75 \mathrm{M}$, and at the bows it is $6.1 \mathrm{M}$. The authors $\mathrm{Z}$. Jingsong et al. [8] have analysed the previous studies and by means of a "fuzzy" logic they presented the domain areas marked as safe passage, passing with increased caution and dangerous situation. The authors have interestingly concluded that the domain depended on the ship's flag, discrepancies in the training of seafarers, skills and cultural background of maritime officers, and values set by the shipping company. Z. Jingsong et al. [8] have come to the conclusion regarding the size of the domain on the open sea by using the "fuzzy" theory and their research results. Davis et al. [5] carried out a survey which included seafarers and asked questions pertaining to the CPA in relation to the ship approaching from the port or starboard, and pertaining to the distance at which to commence avoidance. In general, they responded that the domain for ships approaching from the starboard side was $1.8 \mathrm{M}$, and the action of avoidance would start at $4.3 \mathrm{M}$ distance from another ship. The domain from port side was $1.6 \mathrm{M}$, and the distance for avoidance 2.6 M. Pietrzykowski, et al. [9] presented graphically their research results (Figures 1 and 2) where two ships passed each other on the open sea at a safe distance. The figures show resizing of a domain when two ships of different sizes pass each other in relation to own ship.

Figure 2 shows different sizes of ship domains according to the size of ships.

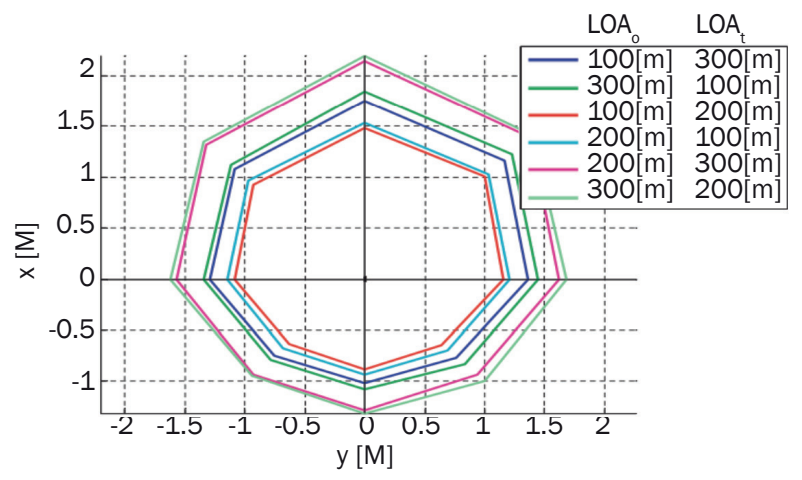

Figure 2 - Ship's domain relative to its size

\section{FACTORS AFFECTING THE DETERMINATION OF THE CLOSEST POINT OF APPROACH}

As already mentioned in the previous section, the CPA depends primarily on the ship manoeuvrability, area of navigation, and accuracy of the ARPA device. This paper deals with the value of CPA within the 
unlimited area of navigation, under assumption that only two ships are approaching each other. In such conditions the CPA primarily depends on the ship manoeuvrability and the accuracy of the ARPA device.

The ship manoeuvrability is determined by the IMO resolution MSC.137 (76) [10]. The standards require the advance not to exceed 4.5 ship lengths $(\mathrm{L})$ at maximum rudder deflection, while tactical diameter should not be greater than 5 ship lengths. If the sea depth is lower than four times the draught, this diameter becomes even greater, but rarely more than 8 ship lengths.

ARPA Performance Standards are defined by the IMO resolution A.823 (19) [11] which requires ARPA to provide accuracies (95\% probability values) within 1 minute of tracking for four scenarios that do not exceed the maximum permissible error listed in Table 1.

Table 1 - The maximum permissible error of ARPA within 1 minute of tracking

\begin{tabular}{||c|c|c|c||}
\hline Scenario & $\begin{array}{c}\text { Relative course } \\
{\left[{ }^{\circ}\right]}\end{array}$ & $\begin{array}{c}\text { Relative speed } \\
{[\mathrm{kt}]}\end{array}$ & $\begin{array}{c}\text { CPA } \\
{[\mathrm{M}]}\end{array}$ \\
\hline \hline 1 & 11 & 2.8 & 1.6 \\
\hline 2 & 7 & 0.6 & - \\
\hline 3 & 14 & 2.2 & 1.8 \\
\hline 4 & 15 & 1.5 & 2.0 \\
\hline
\end{tabular}

The same resolution pertains to the ARPA Performance Standards which require ARPA to provide accuracies (95\% probability values) within 3 minutes of tracking for 4 scenarios that do not exceed the maximum permissible error listed in Table 2.

Table 2 shows that in the two scenarios when determining CPA, ARPA error can reach 0.7 Nm.

\section{RESEARCH ON THE CLOSEST POINT OF APPROACH}

During the last two years the Faculty of Maritime Studies in Rijeka was the leading project manager for the EU research project "Avoiding Collision at SeaACTs". One of the goal of the project was to conduct research related to determining the CPA within the unlimited area of navigation.

The research conducted in 2014 involved 1,530 respondents, but for the purpose of this paper only the results obtained from those with at least one year of navigation were analysed. This sample comprised 225 respondents whose views on the distance at which to start the avoidance action and on the CPA were analysed.

The first scenario presented to respondents was the following: two power-propelled vessels with the LOA $200 \mathrm{~m}$ and the speed of 15 knots are crossing on the open sea with the risk of collision. You are aboard the vessel that gives way. At what distance will you start the action to avoid the collision? The results are presented in Figure 3.

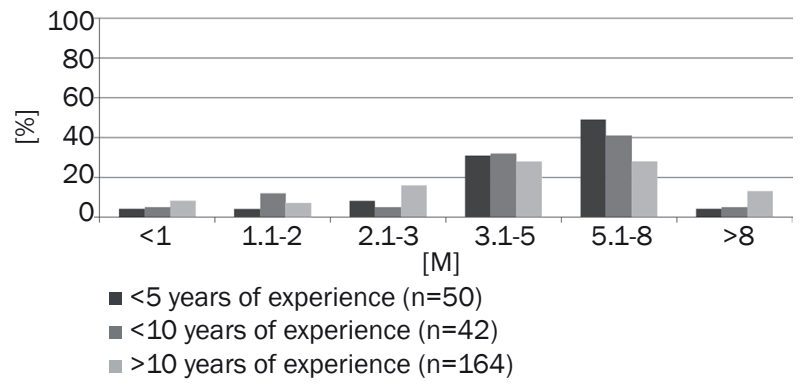

Figure 3 - Percent of answers for distance at which to start the collision avoiding action

The graph shows that the majority of respondents answered that the distance would be 5.1-8 M, and a slightly smaller number of respondents said the distance would be 3.1-5 M.

The second scenario was the following: What do you think is the safe CPA for two power-driven vessels, LOA 200 m, when they meet on the open sea. The results are presented in Figure 4.

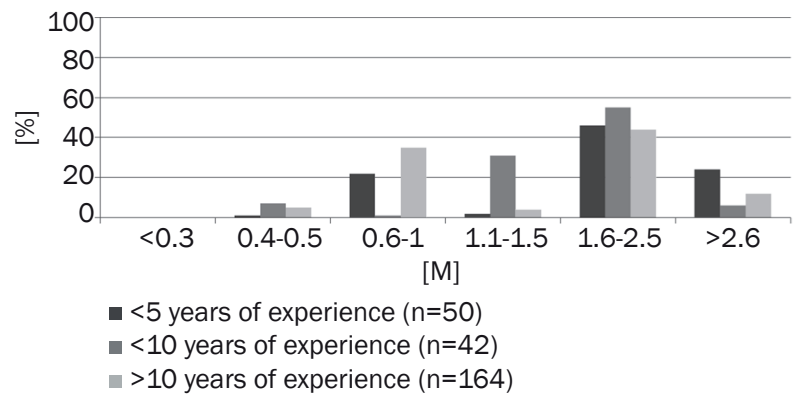

Figure 4 - Percent of answers for minimum CPA opinion testing on the open sea

The obtained results lead to the conclusion that the majority of respondents consider the safest CPA to vary from 1.6 to $2.5 \mathrm{M}$.

Table 2 - The maximum permissible error of ARPA within 3 minutes of tracking

\begin{tabular}{||c|c|c|c|c|c|c||}
\hline Scenario & Relative course $\left[{ }^{\circ}\right.$ ] & Relative speed [kt] & CPA [M] & TCPA [min] & True Course [ ${ }^{\circ}$ ] & True speed [kt] \\
\hline \hline 1 & 3.0 & 0.8 & 0.5 & 1.0 & 7.4 & 1.2 \\
\hline 2 & 2.3 & 0.3 & - & - & 2.8 & 0.8 \\
\hline 3 & 4.4 & 0.9 & 0.7 & 1.0 & 3.3 & 1.0 \\
\hline 4 & 4.6 & 0.8 & 0.7 & 1.0 & 2.6 & 1.2 \\
\hline
\end{tabular}


The aforementioned research was complemented by the one carried out at the University of Dubrovnik Maritime Department in 2015 which included 76 respondents, out of which $20 \%$ were working aboard passenger ships, $13 \%$ on ships transporting liquid cargo, $43 \%$ aboard bulk carriers, $5 \%$ on break bulk ships, $12 \%$ on container ships, and $7 \%$ on other ship types. The respondents were asked the same questions as those participating in the ACTs project.

A total of $55 \%$ of respondents with 10 years of seafaring experience responded that the distance at which they would start collision avoiding action was between 5.1 and $8 \mathrm{M}$, while $30 \%$ said that the distance would be from 3.1 to $5 \mathrm{M}$. These results were in correlation with those obtained within the ACT project.

A total of $60 \%$ of respondents believed that the safe CPA was between 1.1 and $1.5 \mathrm{M}$, while $10 \%$ thought that it was between 0.6 and $1 \mathrm{M}$, and $15 \%$ said that it was between 1.6 and $2.5 \mathrm{M}$. A large number of respondents have chosen the value lower than the one obtained within the ACTs research project. In terms of the aim of the paper, the respondents were asked if there were any set values regarding the CPA on their respective ships according to the International Safety
Management (ISM), and if yes which those values were. The results are shown in Figure 5.

Based on the obtained results it can be concluded that $57 \%$ of respondents do not have or do not determine the CPA; $22 \%$ follow the values specified in the ISM/SMS procedures; $14 \%$ said that CPA of $1 \mathrm{M}$ was specified in the Standing orders, 5\% stated that it was left to the discretion of the ship's master, and 1\% responded that such value was greater than 0.5 and $1.5 \mathrm{M}$.

The comparison of the research carried out at the University of Rijeka and the University of Dubrovnik with former similar studies presented in this paper is not quite possible as previously published papers lack information regarding the size and type of the vessels whose crew participated in the survey, which can significantly affect the research outcome. However, for the sake of the review of the past and current studies, the CPA and DCPA values are presented in Table 3.

Respondents were also asked if they were familiar with the ARPA errors allowed by IMO resolution IMO A.823(19). The results are presented in Figure 6.

The results show that more than $4 / 5$ of respondents are not familiar with the allowed ARPA error.

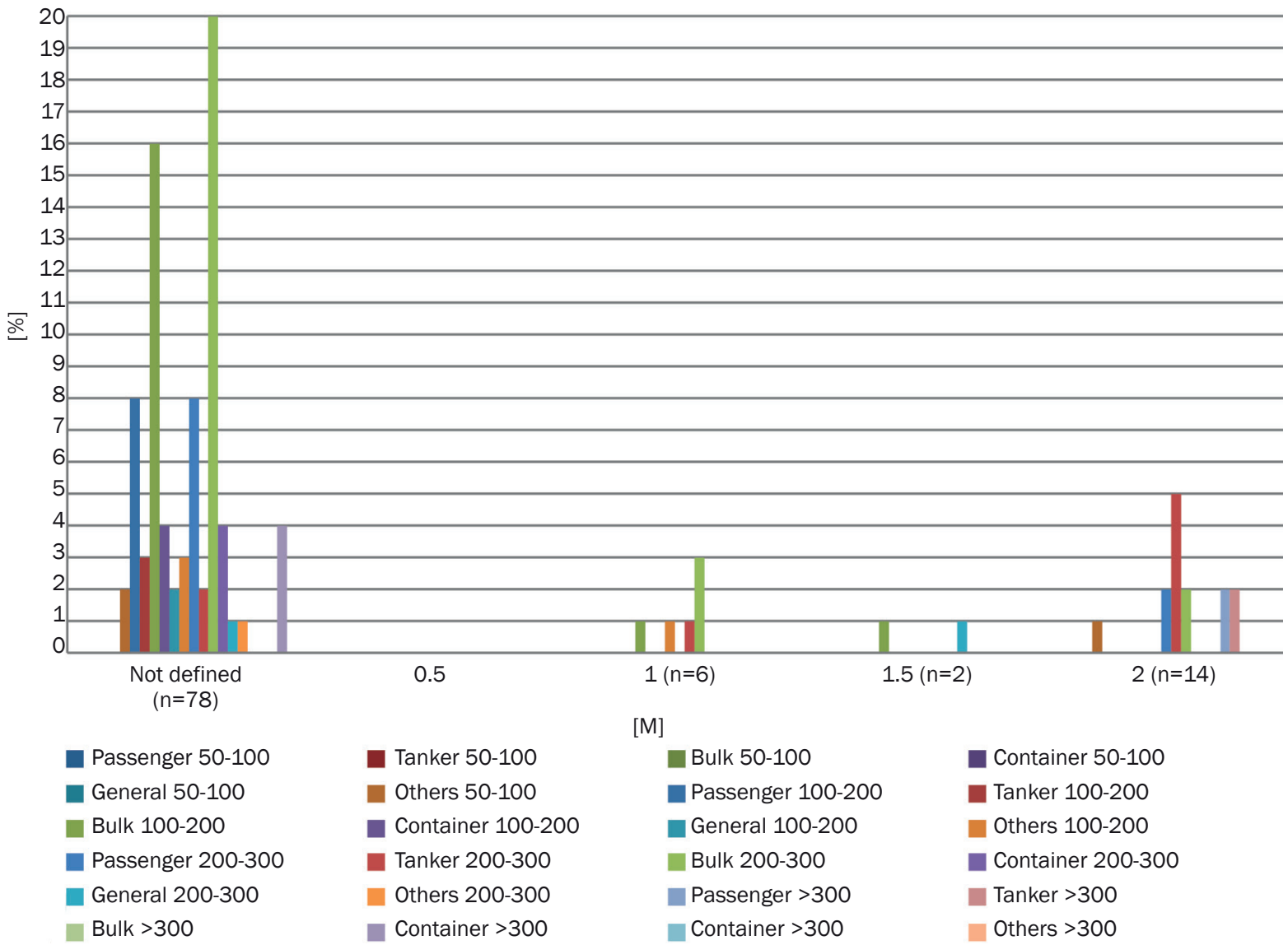

Figure 5 - The percentage of responses for the values of CPA on the open sea as per ISM in terms of the ship type and length 
Table 3 - CPA and DCPA values as per past and current studies

\begin{tabular}{||l|c|c||}
\hline \multicolumn{1}{|c|}{ Authors \& Year } & CPA [M] & DCPA [M] \\
\hline \hline Goodwin (1975) & 2.35 & - \\
\hline Limbach (1977) & - & 5.6 \\
\hline Davis et al. (1980) & 1.8 & 4.3 \\
\hline Pietrzykowski (2009) & $1.5-2.2$ & - \\
\hline University of Rijeka (2014) & $1.6-2.5$ & $5.1-8$ \\
\hline University of Dubrovnik (2015) & $1.1-1.5$ & $5.1-8$ \\
\hline
\end{tabular}

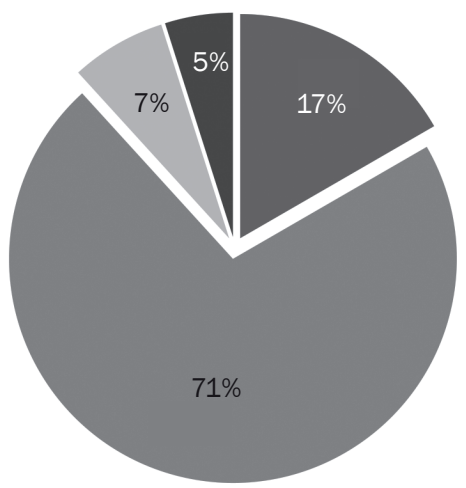

- Not stated $(\mathrm{n}=15)$

- Unknown $(\mathrm{n}=73)$

$0.7 \mathrm{M}(\mathrm{n}=7)$

- 0.0-0.7 M (n=5)

Figure 6 - The percentage of responses regarding the acquaintance with the ARPA error allowed by the IMO resolution A.823(19)

\section{THE MODEL OF DETERMINING THE CLOSEST POINT OF APPROACH}

The author's research results on determining the CPA and the results of survey on the same topic that involved ship officers were presented in the previous sections. Results point to the fact that the values differ significantly and that the method of determining the CPA is very subjective. That is why, based on the study conducted on the nautical simulator, the model for determining the CPA on the open sea will be proposed in this section.

The CPA is most affected by the size of the ship turning circle, and thus in this paper it is taken as the key factor in determining the CPA. Likewise, the simulation on the nautical simulator helped determine the value of resizing of the turning circle at different values of external effects and different rudder deflection angles.

If there are no external influences on the ship, then the size of the turning circle will be determined from the ship manoeuvring diagram, and the movement must not exceed 4.5 ship lengths $(L)$ at the maximum rudder deflection, which will be used as reference value in this paper. Figure 7 shows three possible scenarios depending on the distance where the action to avoid collision with other ship starts.

Figure $7 a$ shows the ship commencing the collision avoidance action by turning to starboard at the maximum rudder deflection at the distance of $4.5 \mathrm{~L}$ from the course of another ship. In this case a collision with another ship would be inevitable. The distance of the ship that takes the avoiding action will be marked as $X$.

In order to avoid the first scenario the ship beam needs to be taken into account, as presented in Figure $7 \mathrm{~b}$. In that case the aforementioned distance increase by half the beam of ships $A$ and $B$ (ship beam will be marked $B$ ). In this case the ships pass at a very short distance, but this is possible only in theory since the interaction of forces brings the two ships closer. Therefore, it is necessary to have an additional value for the impact of interaction (marked $\mathrm{Y}$ ). This scenario is shown in Figure 7c.

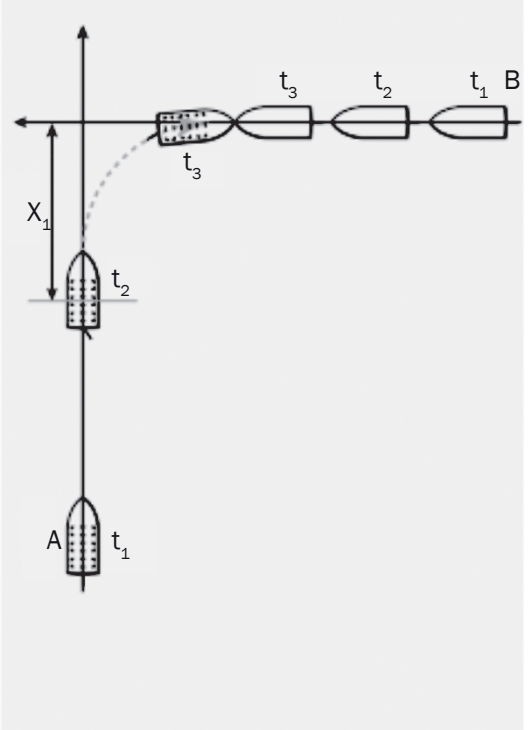

a)

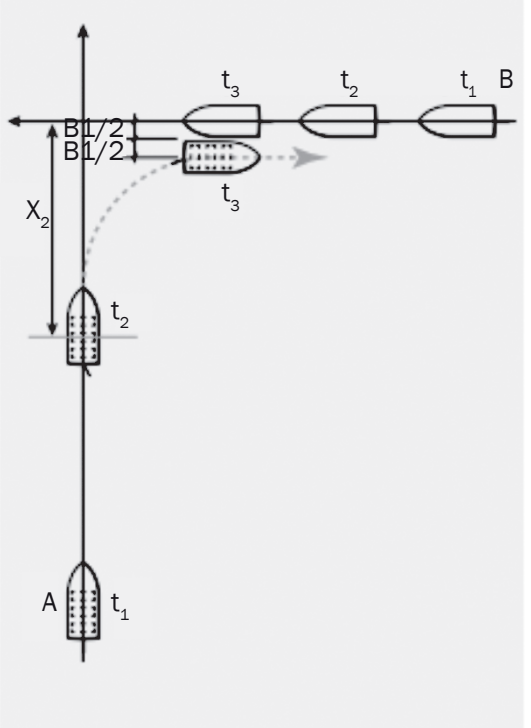

b)

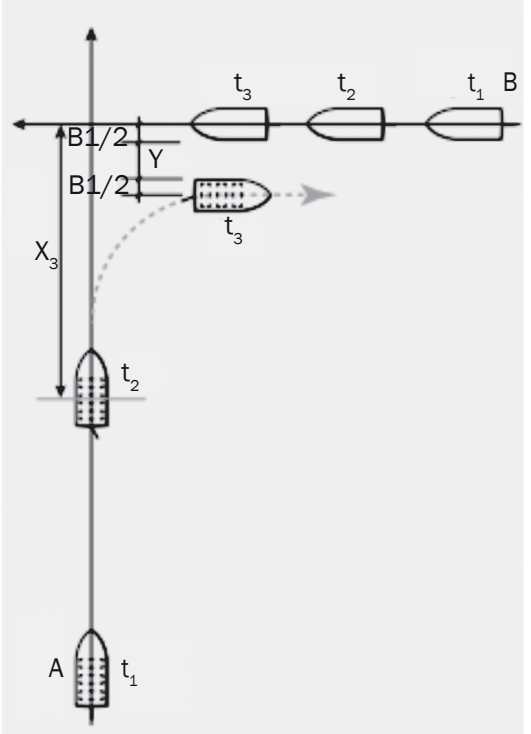

c)

Figure 7 - Ships passing each other depending on the distance of starting the avoidance manoeuvre 
From the aforementioned the expression for scenario $7 \mathrm{c}$ is the following:

$X=4.5 L_{A}+\frac{1}{2} B_{A}+\frac{1}{2} B_{B}+Y$

Many authors have dealt with the interaction between ships. In this paper, the used research results will be those obtained by Clark [12] who says that the effect of interaction occurs when the distance between two shell plating's is shorter than two beams of the wider ship.

This approach to the collision avoidance problem solving cannot be considered safe. According to the literature and COLREGS those ships are in close quarters situation. It is specified in COLREGS that the ship should be manoeuvred to avoid such situation. Therefore, additional studies have been done to create the CPA determining model which can be considered safe.

To obtain the value of increasing the ship turning circle under the influence of wind, waves, and sea current, the studies have been conducted on the Kongsberg ship bridge simulator on the following ship types: - Container - CNTR (displacement 196,390 t, LOA $398.5 \mathrm{~m}$, beam $58.2 \mathrm{~m}$, draught $15.1 \mathrm{~m}$ ),

- Ro-Ro - FERRY (displacement 19,210 t, LOA 199.8 $\mathrm{m}$, beam $26.5 \mathrm{~m}$, draught $7 \mathrm{~m}$ ),

- Tanker - VLCC (displacement 149,336 t, LOA 262 $\mathrm{m}$, beam $42 \mathrm{~m}$, draught $15 \mathrm{~m}$ ).

The first simulation comprised the maximum rudder deflection of $35^{\circ}$ starboard, while the sea currents, waves and wind coming from the stern were selected as the worst case scenario as this helped obtain the maximum drift when the ship is turning. The values of the simulated external effects are the following: a) wind speed $0 \mathrm{~m} / \mathrm{s}$, stream 0 knots, calm;

b) wind speed $5.1 \mathrm{~m} / \mathrm{s}$, stream 1 knots, sea waves on stern;

c) wind speed $10.3 \mathrm{~m} / \mathrm{s}$, stream 2 knots, sea waves on stern;

d) wind speed $15.4 \mathrm{~m} / \mathrm{s}$, stream 3 knots, sea waves on stern.

The implemented simulation gave the values of increased turning circle at various wind, sea current, and wave effects. Table 4 shows the values of movement and tactical diameter for the applied simulations.

Since the maximum rudder deflection angles are not used to avoid collision, especially on the open sea, the studies on the simulator were conducted at $5^{\circ}$, $10^{\circ}, 20^{\circ}$ and $35^{\circ}$ rudder deflection angles. The obtained values are presented in Table 5.

In all previous examples and simulations the values were given for the situation when one ship gives way and the other stands on course in compliance with COLREGs. To determine the safe CPA on the open sea, the possibility of emergency on board ship that has the right of way or the navigation mistake of the officer on watch aboard that ship when he commences the action of avoidance which is not in line with COLREGs must be taken into account. In doing so, the worst case scenario could be the loss of rudder control and its deflection "Full port rudder" or deliberate collision avoidance by the officer on watch aboard ship that has the right of way also by turning to port side. Since these manoeuvres are undertaken at short distances, it can be assumed that the officer on watch would also use the maximum rudder deflection angle. The distance of ship that avoids collision (A) from the other ship course (B) obtained in this way is shown in Figure 8.

Table 4 - The value of movement and tactical diameter in Nm for the simulated situations

\begin{tabular}{|c|c|c|c|c|c|c|c|c|}
\hline \multirow{2}{*}{$\begin{array}{c}\begin{array}{c}\text { Manoeuvring } \\
\text { information } \\
\text { research }\end{array} \\
\text { Ship model }\end{array}$} & \multicolumn{2}{|c|}{$\begin{array}{c}\text { No current } \\
\text { No wind } \\
\text { No wind waves } \\
{\left[\text { Helm order } 35^{\circ}\right]}\end{array}$} & \multicolumn{2}{|c|}{$\begin{array}{c}1 \mathrm{kt} \text { current } \\
5.1 \mathrm{~m} / \mathrm{s} \text { wind } \\
\text { Wind waves } \\
{\left[\text { Helm order } 35^{\circ}\right]}\end{array}$} & \multicolumn{2}{|c|}{$\begin{array}{c}2 \mathrm{kt} \text { current } \\
10.3 \mathrm{~m} / \mathrm{s} \text { wind } \\
\text { Wind waves } \\
{\left[\text { Helm order } 35^{\circ}\right]}\end{array}$} & \multicolumn{2}{|c|}{$\begin{array}{c}3 \mathrm{kt} \text { current } \\
15.4 \mathrm{~m} / \mathrm{s} \text { wind } \\
\text { Wind waves } \\
{\left[\text { Helm order } 35^{\circ}\right]}\end{array}$} \\
\hline & Advance & $\begin{array}{c}\text { Tactical } \\
\text { diameter }\end{array}$ & Advance & $\begin{array}{c}\text { Tactical } \\
\text { diameter }\end{array}$ & Advance & $\begin{array}{c}\text { Tactical } \\
\text { diameter }\end{array}$ & Advance & $\begin{array}{c}\text { Tactical } \\
\text { diameter }\end{array}$ \\
\hline CNTR & 0.66 & 0.62 & 0.69 & 0.63 & 0.73 & 0.64 & 0.78 & 0.67 \\
\hline FERRY & 0.36 & 0.38 & 0.39 & 0.39 & 0.42 & 0.40 & 0.46 & 0.41 \\
\hline VLCC & 0.43 & 0.46 & 0.49 & 0.46 & 0.53 & 0.48 & 0.64 & 0.45 \\
\hline
\end{tabular}

Table 5 - The value of movement and tactical diameter in $\mathrm{Nm}$ for different rudder deflection angles

\begin{tabular}{||c|c|c|c|c|c|c||}
\hline \hline \multirow{2}{*}{$\begin{array}{c}\text { Rudder order } \\
{\left[{ }^{\circ}\right]}\end{array}$} & \multicolumn{2}{|c|}{ CTNR } & \multicolumn{2}{c|}{ FERRY } & \multicolumn{2}{c||}{ VLCC } \\
\cline { 2 - 7 } & Advance & $\begin{array}{c}\text { Tactical } \\
\text { diameter }\end{array}$ & Advance & $\begin{array}{c}\text { Tactical } \\
\text { diameter }\end{array}$ & Advance & $\begin{array}{c}\text { Tactical } \\
\text { diameter }\end{array}$ \\
\hline \hline 5 & 1.64 & 2.38 & 1.01 & 1.73 & 0.86 & 0.91 \\
\hline 10 & 0.98 & 1.15 & 0.69 & 0.95 & 0.65 & 0.72 \\
\hline 20 & 0.70 & 0.78 & 0.32 & 0.61 & 0.45 & 0.55 \\
\hline 35 & 0.65 & 0.63 & 0.34 & 0.39 & 0.43 & 0.46 \\
\hline
\end{tabular}




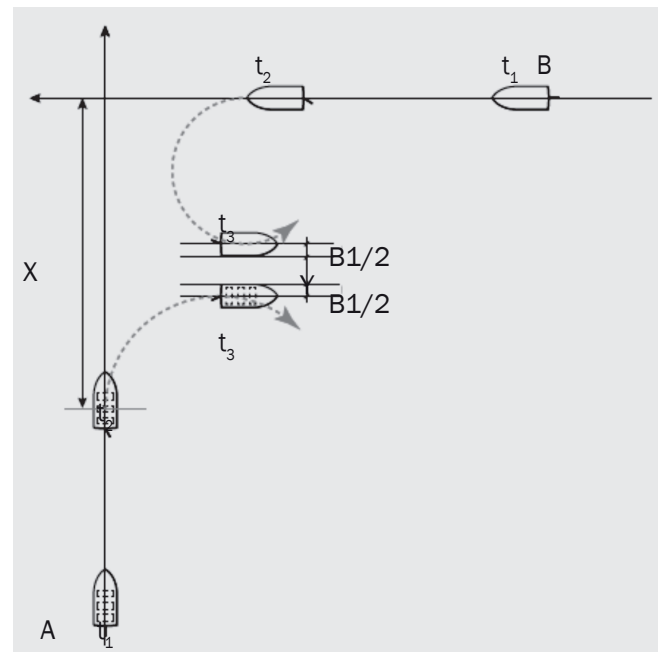

Figure 8 - The scenario when both ships change their course (on purpose or due to the emergency)

Based on the previous explanation the conclusion is that the distance of the ship $(A)$ that avoids collision relative to the other ship's course $(B)$ can be obtained according to the following expression:

$X_{35^{\circ}}=4.5 L_{A}+5 L_{B}+\frac{1}{2} B_{A}+\frac{1}{2} B_{B}+Y \pm Z n$

This expression applies when the rudder deflection angle of the ship that gives way is $35^{\circ}$. The symbols in the expression mean the following: $X$-distance of giveway vessel from course of stand-on vessel, $L_{A}$ and $L_{B}-$ maximum lengths of ships $A$ and $B, B_{A}$ and $B_{B}$-maximum beam of ship $A$ and $B, Y$ - ship interaction value, $Z n$ - advance and tactical diameter extension due to influence of wind, stream and waves.

When the ship avoids collision with $20^{\circ}$ rudder deflection angle, then expression 2 takes the following form:

$$
\begin{aligned}
X_{20^{\circ}}= & \left(4.5 L_{A}+\left(N_{20^{\circ}(L A)}-N_{\left.35^{\circ}(L A)\right)}\right)+5 L_{B}+\right. \\
& +\frac{1}{2} B_{A}+\frac{1}{2} B_{B}+Y \pm Z n
\end{aligned}
$$

where $N$ is the value of ship movement for a specific deflection angle.

The aforementioned expression can be used for any rudder deflection and it becomes the general expression whereby $n$ is the value for rudder deflection angle expressed in degrees.

$$
\begin{aligned}
X_{n^{\circ}}= & \left(4.5 L_{A}+\left(N_{n^{\circ}(L A)}-N_{35^{\circ}(L B)}\right)\right) \\
& +5 L_{B}+\frac{1}{2} B_{A}+\frac{1}{2} B_{B}+Y \pm Z n
\end{aligned}
$$

Simulation of the same scenarios on the ship bridge simulator resulted in slightly lower values due to less movement and smaller tactical diameter on the simulated ships than the maximum allowed by the aforementioned resolution. Such deviations can easily be annulled by the use of data for a specific ship.
The values of $X$ as shown in Table 6, when the ship that gives way starts the action of avoiding collision, cannot be considered safe because if the ship with the right of way does not advance in accordance with COLREGs, the ships can get in the close quarters situation. This conclusion particularly refers to the results obtained for the avoidance manoeuvre which is undertaken by using the $35^{\circ}$ rudder deflection angle, and the results given in the previous table show that the same conclusion applies for the $20^{\circ}$ rudder deflection angle as the differences in obtained values are negligible. In addition to the possible movement of the ship with the right of way which does not comply with COLREGs, the values of possible ARPA error should be taken into account, as shown earlier in this paper.

Table 6 - Values $X$ (in Nm) obtained according to the expression (4) for selected rudder deflection angles for ships used in the research project

\begin{tabular}{||c|c|c|c|c||}
\hline \hline \multirow{2}{*}{ Ship particulars } & \multicolumn{4}{|c|}{ Rudder order } \\
\cline { 2 - 5 } & $5^{\circ}$ & $10^{\circ}$ & $20^{\circ}$ & $35^{\circ}$ \\
\hline \hline $\begin{array}{c}\text { CTNR } \\
(398.5 \mathrm{~m} / 58.2 \mathrm{~m})\end{array}$ & 2.57 & 1.91 & 1.63 & 1.58 \\
\hline $\begin{array}{c}\text { FERRY } \\
(199.8 \mathrm{~m} / 26.5 \mathrm{~m})\end{array}$ & 1.72 & 1.41 & 1.05 & 1.03 \\
\hline $\begin{array}{c}\text { VLCC } \\
(262 \mathrm{~m} / 42 \mathrm{~m})\end{array}$ & 1.66 & 1.45 & 1.25 & 1.23 \\
\hline
\end{tabular}

The previous analysis indicates that a specific value should be added to the obtained results in order to determine the CPA which could be considered safe. Additional distance depends on the value of a possible ARPA error, on the unpredictable behaviour of the officer aboard the encountered ship, and on the possible emergency on the ships that meet. These factors cannot be mathematically determined, but require the inclusion of the risk theory, i.e. the determination of acceptable risk to solve the given problem.

Based on the author's years of experience aboard ships and research conducted with seafarers on navigational simulators (the same target group that participated in other studies described in this paper) it can be noted that the values presented in Table 5 for $20^{\circ}$ and $35^{\circ}$ rudder deflection angles are in fact the values for the CPA between ships on the open sea and not for the distance at which the ship giving way commences the collision avoidance action. The proposed method to determine the CPA represents the minimum value which can be considered safe. By the use of the proposed principle to determine the CPA, in bad sea conditions, two ships will be allowed to pass each other without colliding. It is well known that people differently perceive the value of acceptable risk, and thus in practice different CPA values are obtained, which is presented in the research results, and one of the reasons for such differences is a lack of a systematized and uniform approach proposed in this paper. 


\section{CONCLUSION}

Safety at sea, collision hazard, and hazard avoidance primarily depend on the experience and discretion of a navigator. Personal experience, visual surveillance, COLREGs, ARPA and AIS are all used by the navigator to make timely decisions and thus avoid other ships. COLREGs rules 8 and 16 refer to the vessels passing at a safe distance. Such passing cannot easily be quantitatively defined due to various factors that may affect the determination of this value.

The method presented in this paper pertains to the identification of CPA within the unlimited area of navigation. For the purpose of this paper the avoiding action in the unlimited area of navigation was analysed when ships were in the crossing situation. The situation shown refers to the ships in crossing situation with approximately equal length and speed in bad weather conditions, such as sea currents and wind.

The movement and tactical diameter of the ship were observed in relation to the ship that has the right of way. The answers provided by respondents were analysed and the simulation method was used. The trajectory of different types of ships with various rudder deflections was presented, which makes it possible to correct the domain of the ship, i.e. to get the closest distance for starting the avoidance action. The conclusion is that the ship domain affects the turning cycle, and with the desired CPA value the final distance value is obtained to start turning the ship at specific rudder deflection angle. The future of unmanned ships is in the application of COLREGs, and this very model can be used for that purpose as well.

SRĐAN VUJIČIĆ, mag.ing.naut. ${ }^{1}$

E-mail: srdjan.vujicic@unidu.hr

Dr. sc. ĐANI MOHOVIĆ 2

E-mail: dmohovic@pfri.hr

Dr. sc. ROBERT MOHOVIĆ 2

E-mail: mohovic@pfri.hr

${ }^{1}$ Sveučilište u Dubrovniku, Pomorski odjel

Ćira Carića 4, 20000 Dubrovnik, Hrvatska

2 Sveučilište u Rijeci, Pomorski fakultet

Studentska ulica 2, 51000 Rijeka, Hrvatska

\section{MODEL ODREĐIVANJA NAJMANJE UDALENOSTI MIMOILAŽENJA BRODOVA NA NEOGRANIČENIM PLOVNIM PUTOVIMA}

\section{SAŽETAK}

U ovom radu predložen je model donošenja odluke o pravovremenom izbjegavanju sudara između brodova prilikom križanja kursova na otvorenom moru. Koristeći zahtjeve IMO rezolucije za manevarska obilježja broda, zatim izraza za određivanje vrijednosti najmanje udaljenosti mimoilaženja (CPA) kao i druge parametre vlastitog broda i promatranog broda može se odrediti udaljenost pri kojoj se treba započeti izbjegavanje sudara. Rezultati provedenih istraživanja kod pomorskih časnika i zapovjednika brodova s ciljem utvrđivanja vrijednosti najmanje udaljenosti mimoilaženja (CPA) pokazuju vrlo subjektivne načine procjene. Prikazani model dobiven metodom simulacije za određivanje najmanje udaljenosti mimoilaženja (CPA) između brodova na otvorenom moru ključni je element istraživanja i ostavlja prostor za dodatna istraživanja i primjenu na buduće brodove bez posade.

\section{KLUUČNE RIJEČI}

donošenje odluke pri izbjegavanju sudara; brodska domena; simulacija upravljanja kormilom;

\section{REFERENCES}

[1] Gale H, Patraiko D. Improving navigational safety, Seaways, [Internet]. 2007 Mar. Available from: file:///C:/ Users/Korisnik/Downloads/improving_navigational safety seaways_jul_07\%20(1).pdf

[2] Marine Accident Investigation Branch [Internet]. Bridge watch keeping safety study. [last accessed Nov 2014]. Available from: http://www.maib.gov.uk/cms_resources.cfm?file $=/$

[3] Fujii Y, Tanaka K. Traffic Capacity. The Journal of Navigation.1971 Oct;24(04):543-552.

[4] Goodwin EM. A Statistical Study of Ship Domains. The Journal of Navigation. 1975 Jul;28(03):328-344.

[5] Davis PV, Dove MJ, Stockel CT. A Computer Simulation of Marine Traffic Using Domains and Arenas. Journal of Navigation. 1980 May;33(02):215-222.

[6] Holmes JD. A Statistical Study of Factors Affecting Navigation Decision-making. Journal of Navigation. 1980 May;33(02):206-214.

[7] Coldwell TG. Marine Traffic Behaviour in Restricted Water. The Journal of Navigation. 1983 Sep;36(03): 430-444.

[8] Jingsong Z, Zhaolin W, Fengchen W. Comments on Ship Domains. Journal of Navigation. 1993 Sep; 46(03):422-436.

[9] Pietrzykowski Z, Uriasz J. The Ship Domain - A Criterion of Navigational Safety Assessment in an Open Sea Area. Journal of Navigation. 2009 Jan;62(01):93-108.

[10] International Maritime Organization. Maritime Safety Committee; Resolution MSC137(76):Standard for Ship Manoeuvrability. IMO; 2002.

[11] International Maritime Organization. Maritime Safety Committee; Resolution A.823(19): Performance Standard for Automatic Radar Plotting Aids (ARPAs). IMO; 2002.

[12] Clark IC. Ship Dynamics for Mariners. London: The Nautical Institute; 2005. 